\title{
航空機の 4 制御変数質点モデルの導出とその実用性に関する研究*1 The Research about the Derivation and the Applicability of the Aircraft Four Control Variables Point Mass Model
}

\author{
今 度 史 昭*2 平 家 祐 貴*3 $\cdot$ 木下 拓 也*4
}

Fumiaki Imado, Yuki Heike and Takuya Kinoshita

Key Words : Aircraft, Point Mass Model, Simulation

\begin{abstract}
A new point mass model of the air vehicle has been developed in our laboratory. This model employs angle-of-attack, side slip angle, bank angle and thrust, as four control variables. The existent three control variables point mass model cannot introduce the winds and active side slip angle control, while this new model can introduce them. This paper explains about the model at first. The model is applied to the YF-16 aircraft and simulations are conducted for two maneuvers as typical examples, which show the effectiveness and the preciseness of this model.
\end{abstract}

\section{1. 序章}

航空機の誘導制御系の研究において従来から迎え角，バ ンク角, 推力を制御変数とする質点モデルが使用されてき た . このモデルにおいてはバンク角を取ることにより横滑 り角が 0 に制御されている (Coordinated turn) という近 似が用いられている.また航空機にはオートパイロットと 呼ばれる姿勢制御系が組み込まれており回転運動は短時間 で収束するので, 回転運動は理想的に制御されているもの として航空機を質点で近似し，乥の並進運動の制御系の研 究に用いるものである. 著者らの研究室においても無人航 空機 $(U A V)$ の最適経路制御の研究に従来の質点モデルを 用いてきたが, 岡体としての忠実な機体モデルに適用する 場合, とりわけ風の有る場合の制御には適用できないので 横滑り角を制御変数として導入する必要があると判断した . 最初にウインドシアなどの風が有る場合にどんなモデルが 使用されているか文献を調査したが先れらの大部分が風が 有ると風と共に平行移動する，つまり航空機の慣性を全く 考慮していないモデルや， $\alpha, \beta$ を微小角として近似したモ デルであり, 横滑り角を制御変数として導入した信頼でき るモデルが見つからなかった . 谷こで研究を進めるために 自分たちで1) 4 制御変数質点モデルを導出した . 質点モデ ルはあくまで岡体モデルの近似であるから , このモデルに よって設計したシステムが炎のまま剛体モデルに適用でき るかを確認する必要がある．

そこで，次にこの新しい質点モデルを用いて得られた航 空機飛行制御系の制御指令信号を岡体モデルに与えたとき

\footnotetext{
*1 (C) 2009 日本航空宇宙学会

平成 21 年 4 月 22 日原稿受理

$* 2$ 信州大学工学部

*3 全日本空輸(株) 整備本部

$* 4$ 防衛省航空自衛隊
}

に同じように飛行するかの検討を行った . 兴の結果, 著者ら が導いた 4 制御変数質点モデルを用いて設計, シミュレー ションを行った結果は十分な精度で岡体の航空機モデルに 適用できることが分かった．本稿の 2 章において新しい質 点モデルについて説明する . 剛体モデルと比較するために は質点モデルに与える制御指令信号と同じものを剛体モデ ルに与えたとき, 指令通りに運動するように岡体モデルの 制御系を設計しなければならない.3 章においてこれらの制 御系について説明する . 次に質点モデル , 及び上記の制御 系を組み込んだ岡体モデルについて 2 種類の航空機マヌー バを行わせて比較検討を行った . 4 章においてはこれらの 結果について説明する .5 章は本稿における結論である .

\section{4 制御変数質点モデル}

新たに開発した 4 制御変数質点モデルの座標系と主な変 数を第 1 図に示す. 航空機の運動方程式は (1)〜 (6) で与え られる。

$$
\begin{aligned}
\dot{V}= & \frac{T \cos \phi \cos \beta-D^{\prime}}{m}-g \sin \gamma \\
\dot{\gamma}= & \frac{T(\cos \phi \sin \alpha+\sin \alpha \cos \alpha \sin \beta)+L^{\prime} \cos \phi+C^{\prime} \sin \phi}{m V} \\
& -g \cos \gamma / V \\
\dot{\psi}= & \frac{T(\sin \phi \sin \alpha-\cos \phi \cos \alpha \sin \beta)+L^{\prime} \sin \phi-C^{\prime} \cos \phi}{m V \cos \gamma} \\
\dot{x}= & V \cos \gamma \cos \psi \\
\dot{y} & =V \cos \gamma \sin \psi \\
\dot{h} & =V \sin \gamma \quad(h=-z)
\end{aligned}
$$

式 (1)〜 (6) は, 第 1 図の $V$ (対地速度ベクトル) 軸上で立 式されたものであり, 風軸座標系の $x$ 軸は航空機で用いら れているオイラ一角の定義に従って, 慣性座標系を $z, y, x$ 


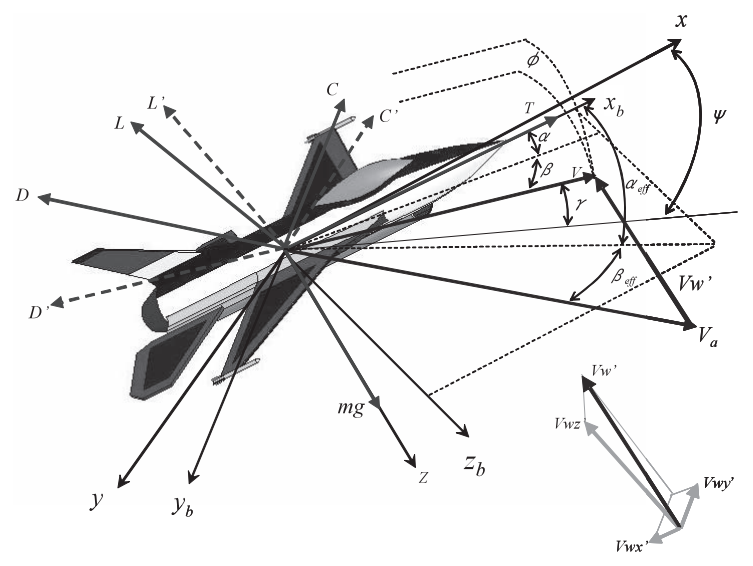

第 1 図 4 制御変数質点モデル

軸まわりに順次方位角 $\psi$, 経路角 $\gamma$, バンク角 $\phi$ の順に回 転することにより座標変換されて $V$ 軸に至る.推力につ いては, 機体固定座標系から $y, z$ 軸まわりに順次迎え角 $-\alpha$, 横滑り角 $\beta$ の順に座標変換されて $V$ 軸に至る.

同図において， $V_{\mathrm{w}}^{\prime}$ は風の速度ベクトル， $V_{\mathrm{w} x}^{\prime}, V_{\mathrm{w} y}^{\prime}, V_{\mathrm{w} z}^{\prime}$ は光の機体固定座標成分である．航空機から見た迎え角， 横滑り角にはこの風による成分が加わるのでこれらを $\alpha_{\mathrm{eff}}$ ， $\beta_{\text {eff }}$ とする.また，機体に働く揚力，抗力，横力は，光れ 次式のように定義している。

$$
\begin{aligned}
& L=Q S C_{\mathrm{L}}\left(\alpha_{\mathrm{eff}}, \beta_{\mathrm{eff}}\right) \\
& D=Q S C_{\mathrm{D}}\left(\alpha_{\mathrm{eff}}, \beta_{\mathrm{eff}}\right) \\
& C=Q S C_{\mathrm{C}}\left(\alpha_{\mathrm{eff}}, \beta_{\mathrm{eff}}\right)
\end{aligned}
$$

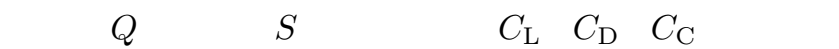
れ揚力係数, 抗力係数, 横力係数で $C_{\mathrm{C}}$ は風軸の $-Y$ 方向 を正として定義される. 各空力係数については, 剛体モデ ルの飛行特性とよく一致するように, 両モデルの飛行シミュ レーションによって挙動を比較し， $\alpha_{\mathrm{eff}}, \beta_{\mathrm{eff}}$ のテーブル関 数として与える. 各空力パラメータの推定については後述 する.また，これらの力は座標変換行列 $E$ を用いて， $V_{\mathrm{a}}$ 軸 から $V$ 軸上の $L^{\prime}, D^{\prime}, C^{\prime}$ に変換する. 行列 $E_{2}$ は $V_{\mathrm{a}}$ 軸 から機体固定座標系への座標変換行列であり, 行列 $E_{1}$ は 機体固定座標系から $V$ 軸への変換行列である .

$$
\begin{aligned}
& \left(D^{\prime} C^{\prime} L^{\prime}\right)^{\mathrm{T}}=E(D C L)^{\mathrm{T}} \\
& E=E_{1} E_{2} \\
& E_{1}=\left(\begin{array}{ccc}
\cos \alpha \cos \beta & \sin \beta & \sin \alpha \cos \beta \\
-\cos \alpha \sin \beta & \cos \beta & -\sin \alpha \sin \beta \\
-\sin \alpha & 0 & \cos \alpha
\end{array}\right) \\
& E_{2}=\left(\begin{array}{ccc}
\cos \alpha_{\mathrm{eff}} \cos \beta_{\mathrm{eff}} & -\cos \alpha_{\mathrm{eff}} \sin \beta_{\mathrm{eff}} & -\sin \alpha_{\mathrm{eff}} \\
\sin \beta_{\mathrm{eff}} & \cos \beta_{\mathrm{eff}} & 0 \\
\sin \alpha_{\mathrm{eff}} \cos \beta_{\mathrm{eff}} & \sin \alpha_{\mathrm{eff}} \sin \beta_{\mathrm{eff}} & \cos \alpha_{\mathrm{eff}}
\end{array}\right)
\end{aligned}
$$

また，有効迎え角，有効横滑り角，対気速度，動圧につい

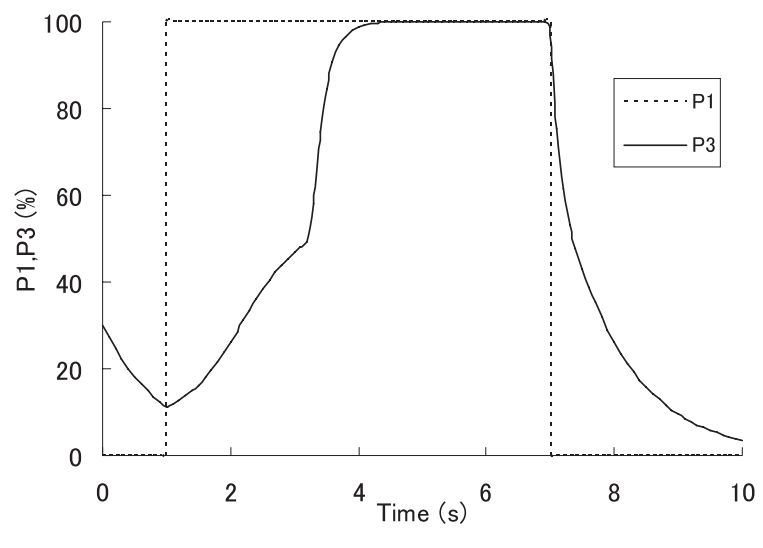

第 2 図 PWF-100 エンジンのステップ応答

ては式 (14)〜(16) で定義できる .

$$
\begin{aligned}
& \alpha_{\mathrm{eff}}=\tan ^{-1}\left(\frac{V \sin \alpha \cos \beta-V_{\mathrm{w} z}^{\prime}}{V \cos \alpha \cos \beta-V_{\mathrm{w} x}^{\prime}}\right) \\
& \beta_{\mathrm{eff}}=\sin ^{-1}\left(\frac{V \sin \beta-V_{\mathrm{w} y}^{\prime}}{V_{\mathrm{a}}}\right) \\
& V_{\mathrm{a}}=\sqrt{V_{\mathrm{a} x}^{2}+V_{\mathrm{a} y}^{2}+V_{\mathrm{a} z}^{2}} \\
& V_{\mathrm{a} x}=V \cos \alpha \cos \beta-V_{\mathrm{w} x}^{\prime} \\
& V_{\mathrm{a} y}=V \sin \beta-V_{\mathrm{w} y}^{\prime} \\
& V_{\mathrm{a} z}=V \sin \alpha \cos \beta-V_{\mathrm{w} z}^{\prime} \\
& Q=\frac{1}{2} \rho V_{\mathrm{a}}^{2}
\end{aligned}
$$

一方，機体のダイナミクスに高次の振動モードを有して いては良好な計算解を得ることが困難となる，乥こで，本 質点モデルの姿勢制御ループは速やかに安定化されるもの と仮定し，姿勢制御系は機体時定数と制御系時定数を含め た等価時定数を用いて次式のように 1 次遅れ系で近似でき るものとした .

$$
\begin{aligned}
& \dot{\alpha}=\frac{\alpha_{\mathrm{c}}-\alpha}{\tau_{\alpha}} \\
& \dot{\beta}=\frac{\beta_{\mathrm{c}}-\beta}{\tau_{\beta}} \\
& \dot{\phi}=\frac{\phi_{\mathrm{c}}-\phi}{\tau_{\phi}}
\end{aligned}
$$

ここで用いた航空機のデータは質点モデルも剛体モデル もすべて文献 2) YF-16 によっている . エンジンは PWF100 で指令信号に対する出力特性は両モデルとも文献 2)に 示される通りである . 紙面の都合でここでは光のステップ 応答のみを第 2 図に示す . P1 が入力 , P 3 が出力である. 次に空力係数の Fitting について説明する . 前述のオート パイロットを組み込んだ岡体モデルの飛行特性によく一致 する質点モデルの 6 つの適切なパラメータ值 $C_{\mathrm{L}}\left(\alpha_{\mathrm{eff}}, \beta_{\mathrm{eff}}\right)$, $C_{\mathrm{D}}\left(\alpha_{\mathrm{eff}}, \beta_{\mathrm{eff}}\right), C_{\mathrm{C}}\left(\alpha_{\mathrm{eff}}, \beta_{\mathrm{eff}}\right), \tau_{\alpha}, \tau_{\beta}, \tau_{\phi}$ の值を定めるた め, 文献 3) の UAV フライト・シミュレータを用いて次の ような手順を実施した .

(1) 初めに YF-16 戦闘機の風洞試験データをもとに,コー 
第 1 表 求められた質点モデルにおける空力係数

\begin{tabular}{|c|c|c|c|c|c|c|c|}
\hline \multirow[b]{2}{*}{$\alpha$} & \multicolumn{7}{|c|}{$\bar{\beta}$} \\
\hline & -7.5 & -5 & -2.5 & 0 & 2.5 & 5 & 7.5 \\
\hline-10 & -0.02394 & -0.02638 & -0.02502 & -0.02413 & -0.02395 & -0.02403 & -0.02148 \\
\hline-5 & -0.02364 & -0.02437 & -0.02514 & -0.02607 & -0.02472 & -0.02341 & -0.02196 \\
\hline 0 & -0.02137 & -0.02231 & -0.02296 & -0.02364 & -0.02213 & -0.02071 & -0.02014 \\
\hline 5 & -0.00785 & -0.00876 & -0.00753 & -0.00162 & -0.00584 & -0.00562 & -0.00431 \\
\hline 10 & 0.00592 & 0.00571 & 0.00711 & 0.00837 & 0.00807 & 0.00787 & 0.00843 \\
\hline 15 & 0.01093 & 0.00807 & 0.00503 & 0.00225 & 0.00632 & 0.00916 & 0.01003 \\
\hline 20 & 0.01256 & 0.01120 & 0.01037 & 0.00481 & 0.01055 & 0.00866 & 0.00694 \\
\hline \multicolumn{8}{|l|}{$C_{Y}$} \\
\hline & \multicolumn{7}{|c|}{$\bar{\beta}$} \\
\hline$\alpha$ & -7.5 & -5 & -2.5 & 0 & 2.5 & 5 & 7.5 \\
\hline-10 & 0.05661 & 0.02428 & 0.01301 & 0.00037 & -0.01103 & -0.01915 & -0.04921 \\
\hline-5 & 0.08320 & 0.05934 & 0.03006 & -0.00311 & -0.02592 & -0.04771 & -0.07772 \\
\hline 0 & 0.14085 & 0.16021 & 0.07885 & -0.00374 & -0.03074 & -0.05807 & -0.09157 \\
\hline 5 & 0.09816 & 0.06522 & 0.03177 & -0.00132 & -0.03025 & -0.06163 & -0.09339 \\
\hline 10 & 0.10169 & 0.06355 & 0.03506 & 0.00555 & -0.02124 & -0.04693 & -0.08840 \\
\hline 15 & 0.09419 & 0.05773 & 0.02499 & -0.00575 & -0.02838 & -0.05022 & -0.08531 \\
\hline 20 & 0.09038 & 0.06106 & 0.02546 & -0.00401 & -0.03366 & -0.05952 & -0.09963 \\
\hline \multicolumn{8}{|l|}{$C_{Z}$} \\
\hline & \multicolumn{7}{|c|}{$\bar{\beta}$} \\
\hline$\alpha$ & -7.5 & -5 & -2.5 & 0 & 2.5 & 5 & 7.5 \\
\hline-10 & 0.81829 & 0.81859 & 0.78621 & 0.76160 & 0.74738 & 0.73315 & 0.71751 \\
\hline-5 & 0.39639 & 0.40661 & 0.36960 & 0.34916 & 0.33172 & 0.30814 & 0.32795 \\
\hline 0 & -0.01792 & -0.01129 & -0.03003 & -0.04671 & -0.06962 & -0.08800 & -0.07685 \\
\hline 5 & -0.41566 & -0.42431 & -0.45424 & -0.48248 & -0.46921 & -0.45165 & -0.45508 \\
\hline 10 & -0.84608 & -0.85081 & -0.88229 & -0.91118 & -0.92172 & -0.93412 & -0.87308 \\
\hline 15 & -1.30432 & -1.28742 & -1.28652 & -1.27651 & -1.35113 & -1.35003 & -1.36811 \\
\hline 20 & -1.60164 & -1.63972 & -1.63583 & -1.62882 & -1.67816 & -1.69128 & -1.75521 \\
\hline
\end{tabular}

ディネート・ターン時の各空力パラメータ值 $C_{\mathrm{L}}\left(\alpha_{\mathrm{eff}}, 0\right)$, $C_{\mathrm{D}}\left(\alpha_{\mathrm{eff}}, 0\right), C_{\mathrm{C}}\left(\alpha_{\mathrm{eff}}, 0\right)$ を推定する . また , 非線形岡体モ デルのオートパイロットのシミュレーション結果をもとに， 各等価時定数 $\tau_{\alpha}, \tau_{\beta}, \tau_{\phi}$ を推定する.

(2) 次に, 各推定值を適用した質点モデルを用いて , コー ディネート・ターンによる飛行シミュレーションを実施する．

(3) 同条件下て䇆体モデルの飛行シミュレーションを行い， 各モデルのシミュレーション結果を比較してパラメータ值 を修正する．

(4) 上記の (2) と (3)を試行錯誤的に数回繰り返すことで , 最 終的にコーディネート・ターン時の良好な質点モデルのパ ラメータ值を得る.

(5) 次に , (4)で得られたパラメータ值と YF-16戦闘機の風 洞試験データをもとに, 横滑り角を発生させた場合の各空力 パラメータ値 $C_{\mathrm{L}}\left(\alpha_{\mathrm{eff}}, \beta_{\mathrm{eff}}\right), C_{\mathrm{D}}\left(\alpha_{\mathrm{eff}}, \beta_{\mathrm{eff}}\right), C_{\mathrm{C}}\left(\alpha_{\mathrm{eff}}, \beta_{\mathrm{eff}}\right)$ を推定する .

(6) 各推定值を適用した質点モデルを用いて, 横滑り角を 用いた飛行シミュレーションを実施する .

(7) 同条件下で岡体モデルの飛行シミュレーションを行い， 各モデルのシミュレーション結果を比較してパラメータ值 を修正する .

(8) 上記の (6) と (7)を試行錯誤的に数回繰り返すことで , 最 終的に良好な質点モデルのパラメータ値を得る .

本推定法により得られたパラメータ值のうち $C_{\mathrm{L}}\left(\alpha_{\mathrm{eff}}\right.$, $\left.\beta_{\mathrm{eff}}\right), C_{\mathrm{D}}\left(\alpha_{\mathrm{eff}}, \beta_{\mathrm{eff}}\right), C_{\mathrm{C}}\left(\alpha_{\mathrm{eff}}, \beta_{\mathrm{eff}}\right)$ については幾つかの
迎え角と横滑り角に対して適切な值を推定し，乥れらの推 定值を用いて線形補間を行っている.以下の章に示したケー スについて求めた空力係数の值を第 1 表に示す. 剛体モデ ルにおいては空力係数は $C_{X}, C_{Y}, C_{Z}$ で表されているの で質点モデルにおいても便宜上 $C_{X}, C_{Y}, C_{Z}$ に変換して 示した．ここで両者の関係は次式で与えられる．

$$
\begin{aligned}
& C_{\mathrm{L}}=C_{X} \sin \alpha-C_{Z} \cos \alpha \\
& C_{\mathrm{D}}=-C_{X} \cos \alpha \cos \beta-C_{Y} \sin \beta-C_{Z} \sin \alpha \cos \beta \\
& C_{\mathrm{C}}=C_{X} \cos \alpha \sin \beta-C_{Y} \cos \beta+C_{Z} \sin \alpha \sin \beta
\end{aligned}
$$

また $\tau_{\alpha}, \tau_{\beta}, \tau_{\phi}$ の値については午れ㢳れ一定値と仮定し， それ光れ $0.4[\mathrm{~s}], 0.4[\mathrm{~s}], 0.45[\mathrm{~s}]$ の值を得た .

\section{3. 剛体モデルの制御系}

岡体モデルの機体制御系は，迎え角，バンク角，横滑り 角を制御変数とするオートパイロットを設計した . 具体的 には，縦系及び横・方向系の 2 組に分けて設計し，縦系の オートパイロットについては迎え角, 横・方向系のオートパ イロットについてはバンク角と横滑り角を制御変数として 設計した .なお，本稿の以下に示すケースについては各制 御系は高度 $3000[\mathrm{~m}]$ を $200[\mathrm{~m} / \mathrm{s}]$ で巡航している場合を設 計点としており, 各フィードバックゲイン等はシミュレー ションを行い試行錯誤的に決定した . 


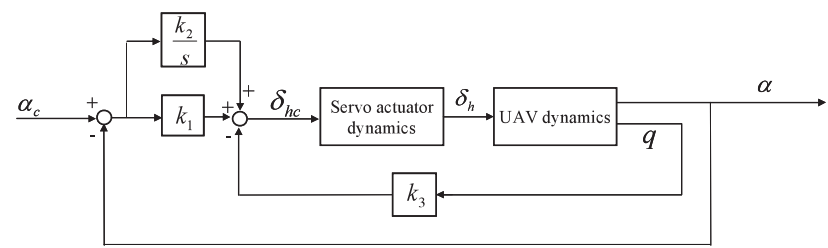

第3図＼cjkstart縦系オートパイロットのブロック線図

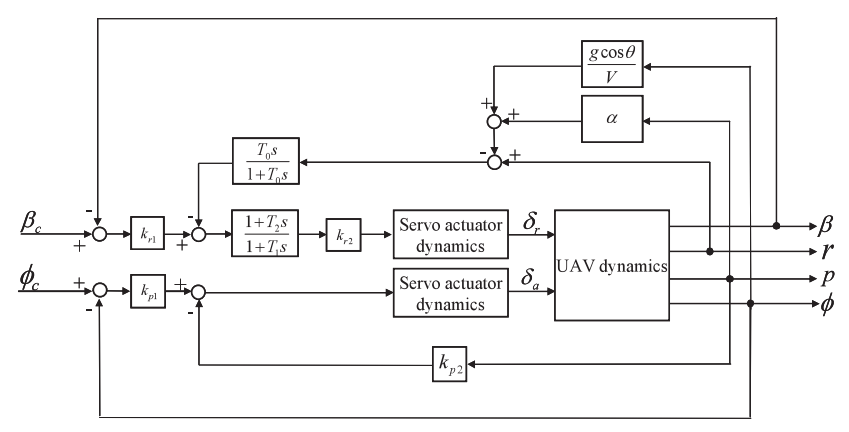

第 4 図＼cjkstart横・方向系オートパイロットのブロック線図

縦系のオートパイロットは, 迎え角とピッチ角速度のフ ィードバック制御系として構成した．また，定常偏差を少 なくするために偏差の積分を付加している. 今回設計した オートパイロットのブロック線図を第 3 図に示す .

横滑り角については, ロール時に発生する横滑り角を減 少させる方法をべースにオートパイロットを構成した .こ の横滑りを減少させる方法は種々検討されているが, 今回 は横・方向系の運動方程式よりターンコーディネーション 関係式を導き，横滑り抑止システムを組んだ上で, 同シス テムを拡張する形で横滑り角に関するオートパイロットを 構成した . ここで旋回時やクラブ飛行時には $r$ を定常的に 出す必要があるが, $r$ を直接 $\delta_{r}$ にフィードバックすると $\delta_{r}$ が $r$ を小さくしようとして阻害信号を出し, 不要な横 滑りを発生させてしまう.この問題を解決するため, ウオッ シュアウトフィルタを通してフィードバックすることにし た .これにより，rのトランジェントな動きに対して $\delta_{r}$ は 作動するが, $r$ の定常値には反応しないため, ダッチロー ルの減衰を高めることができる.さらに, 横滑り角の定常 偏差を少なくするために, アクチュエータの前にリードラ グフィルタを追加した .

また , バンク角については , バンク角のフィードバック に加え，ダンパループとしてバンク角速度のフィードバッ クループを構成した . 第 4 图に横・方向系のオートパイロッ トのブロック線図を示す．

推力制御系では航空機か安定な飛行状態を保ちつつ,さ らに所望の機体速度を実現させるための制御入力を生成さ せる必要がある. 本研究では推力の指令値は速度指令值と 実際の対気速度の誤差に比例させて与え, さらに, 重力と 空気抵抗に対する補償項を付加するように生成している。 第 5 図に本推力制御系の簡易ブロック線図を示す .ここで $T_{\text {bias }}, T_{\text {st }}$ は重力に対する補償項と空気抵抗に対する補償 項を乥れ表している。

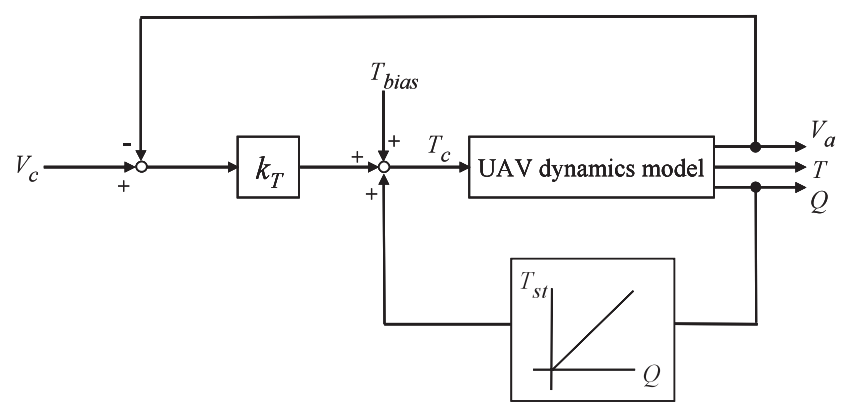

第 5 図推力制御系のブロック線図

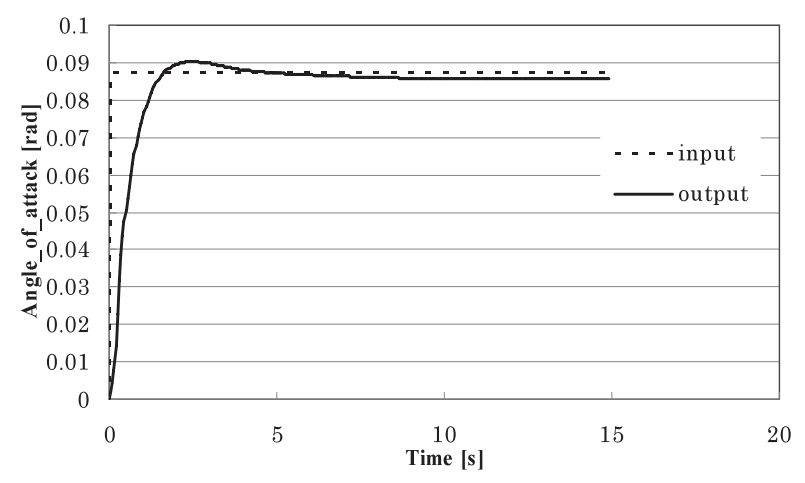

第 6 図 迎え角のステップ応答 $\left(\alpha_{\mathrm{c}}=0.0873[\mathrm{rad}]\right)$

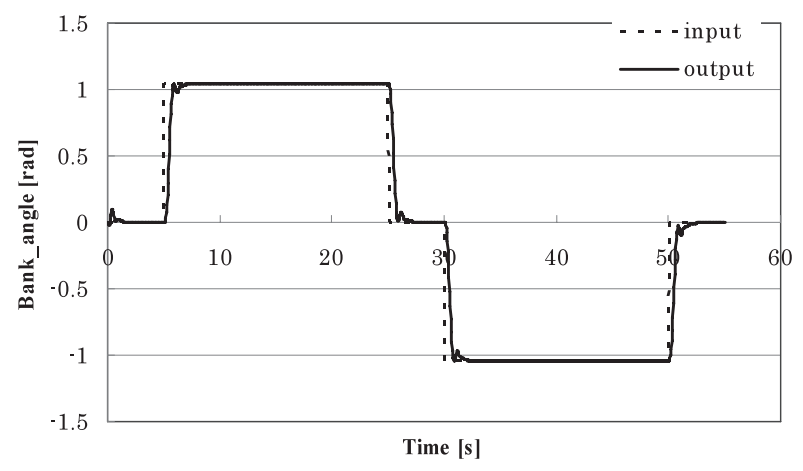

第 7 図 バンク角のステップ応答 $\left(\phi_{\mathrm{c}}=1.0472[\mathrm{rad}]\right)$

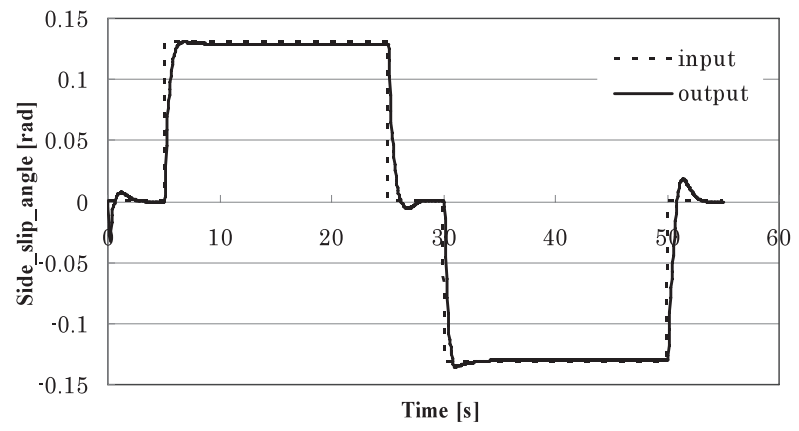

第 8 図 横滑り角のステップ応答 $\left(\beta_{\mathrm{c}}=0.1309[\mathrm{rad}]\right)$

第 6〜10 図に設計した制御系についてステップ応答を 示す.

\section{4 変数質点モデルと 剛体モデルの比較検討}

著者らが導いた質点モデルと剛体モデルの飛行特性を比 


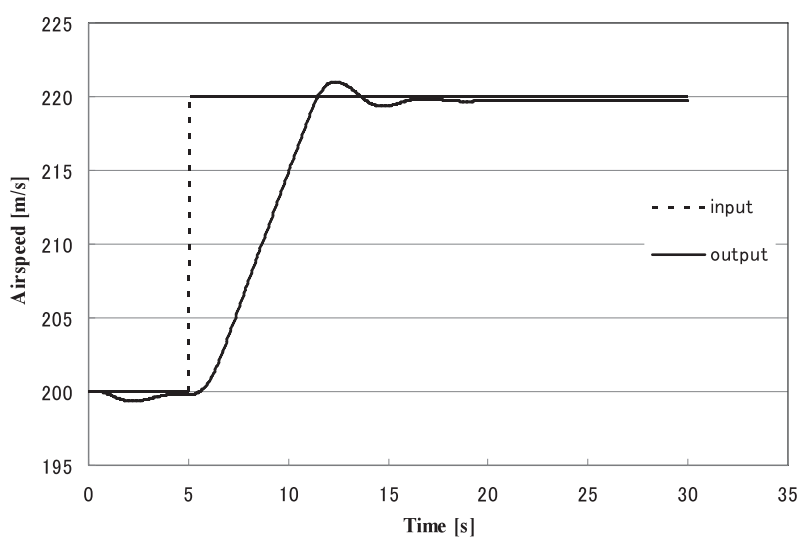

第 9 図 対気速度のステップ応答

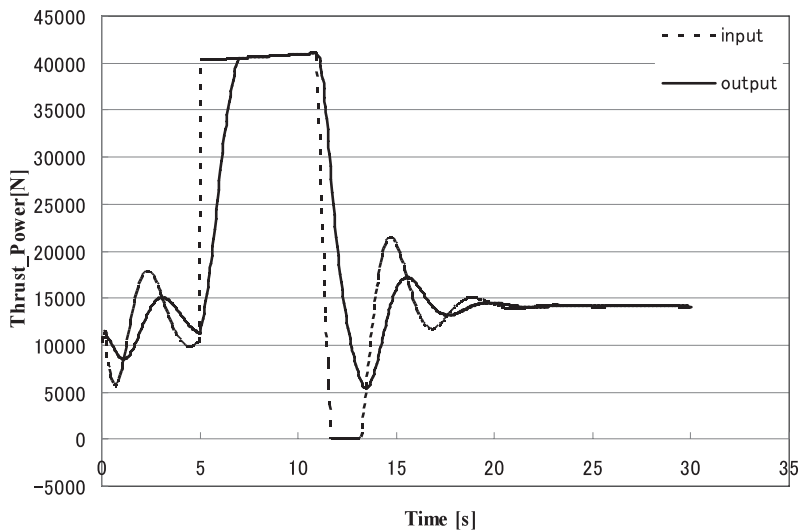

第 10 図 推力のステップ応答 (ミリタリー推力)

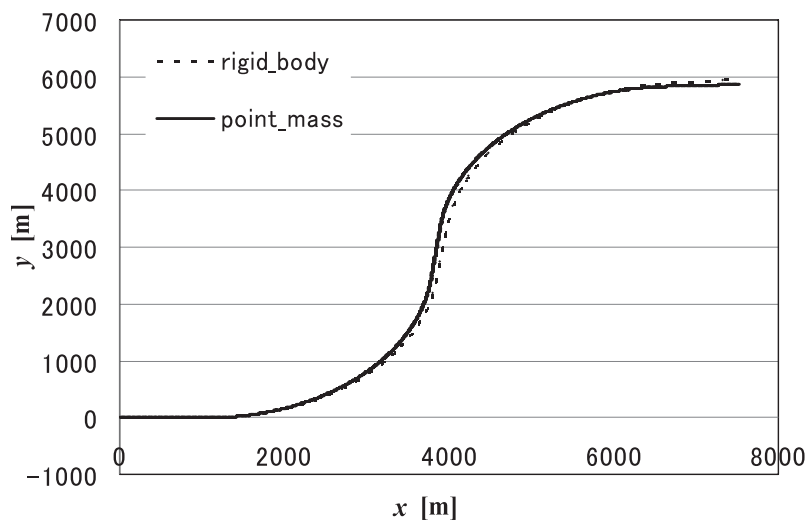

第11図 $\quad x-y$ 平面飛行軌跡

較するため，両モデルに同じ制御入力を与えてシミュレー ションを行い，光れにより実現された各モデルのマヌーバ を乥れ比較する．ここで, 従来の質点モデルにおいて は横滑り角は常に0であるが, 新しい質点モデルにおいて はバンク角と横滑り角を独立に制御できることを示す．以 下本章において, 乥れらのシミュレーション結果の中から 2 つの例を紹介する .

マヌーバ 1 : 速度 $200[\mathrm{~m} / \mathrm{s}]$, 迎え角 $2.5[\mathrm{deg}]$, 横滑り角 $0.0[\mathrm{deg}]$ を一定に保ち，バンク角制御により左右に連続旋 回を行った場合 .

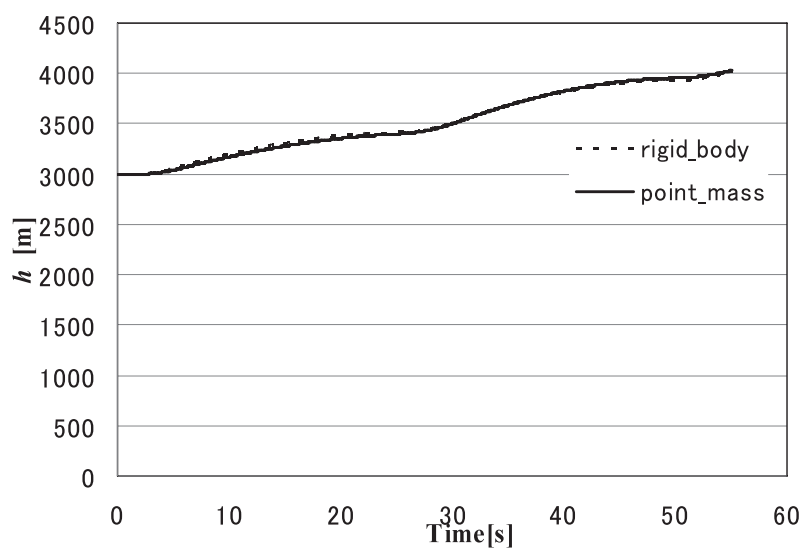

第 12 図高度の時間履歴

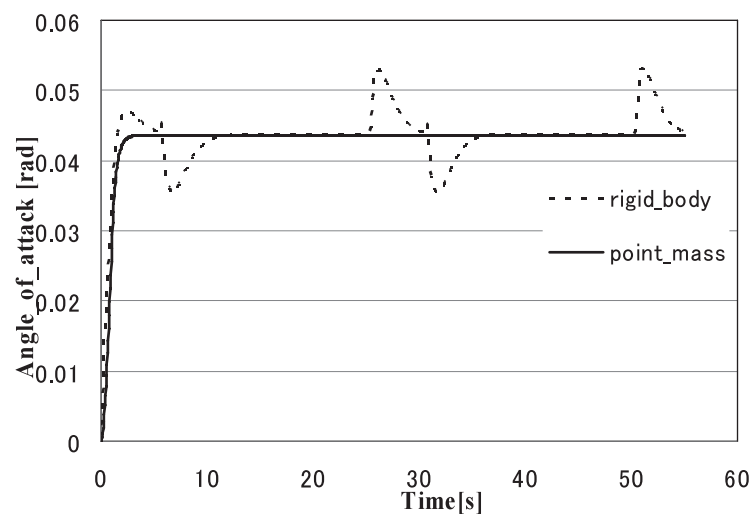

第 13 図 迎え角の時間履歴

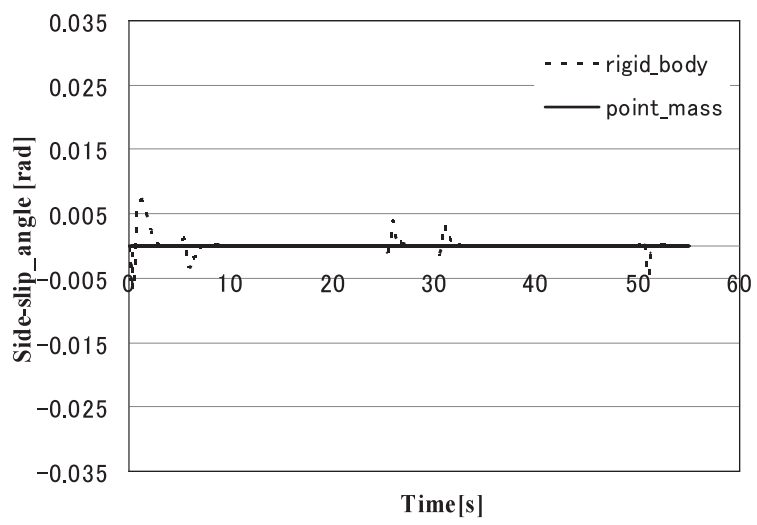

第 14 図 横滑り角の時間履歴

第 11 図と第 12 図は光れ光れ $x-y$ 平面飛行軌跡と高度 の時間履歴である .これらの結果より，両モデルとも明ら かに所期のマヌーバを実現していることが分かる .ここで， 最大位置誤差は約 $100[\mathrm{~m}]$ 程度であり，飛行時間と飛行距 離，機体の速度を考慮すれば実現された両モデルの飛行軌 跡はよく一致していると言える. 第 13 図から第 16 図は， このケースの各制御変数に関する時間履歴である.これよ り，剛体モデルの出力には，周波数の高い制御入力が与え られた部分においてオーバーシュートが生じており，この 点でモデル間の相違が表れているが , 全般的に両モデル間 


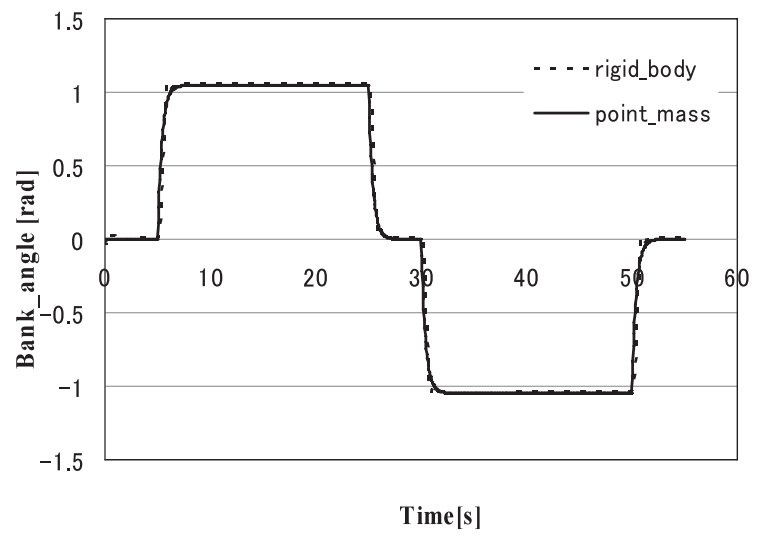

第 15 図 バンク角の時間履歴

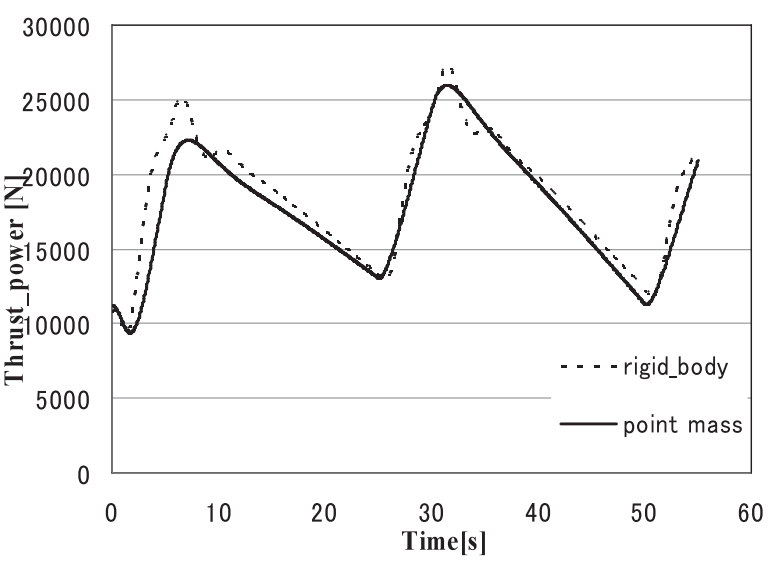

第 16 図 推力の時間履歴

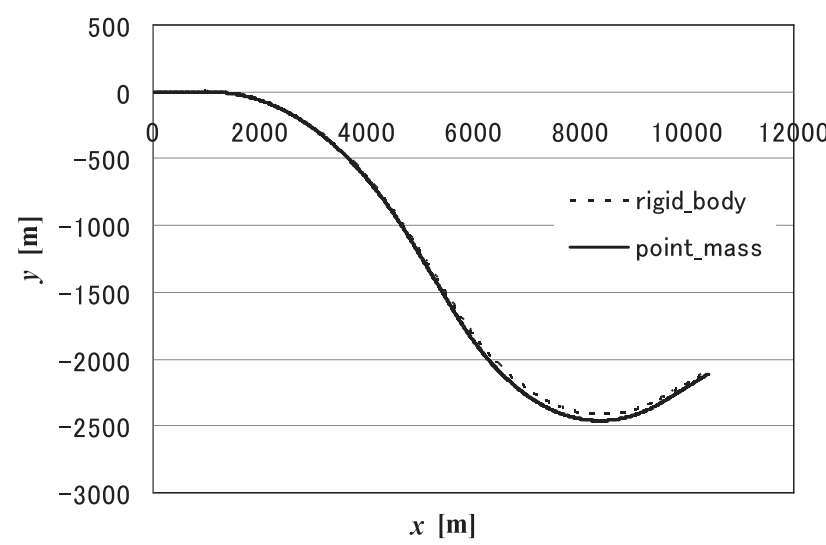

第 17 図 $\quad x-y$ 平面飛行軌跡

における差は小さい．

マヌーバ $2:$ 速度 $200[\mathrm{~m} / \mathrm{s}]$, 迎え角 $1.25[\mathrm{deg}]$, バンク 角 0.0 [deg] を一定に保ち，横滑り角制御により左右に連続 旋回を行った場合。

第 17 図と第 18 図は光れ光れ $x-y$ 平面飛行軌跡と高度 の時間履歴である .これらの結果より，両モデルとも明ら かに所期のマヌーバを実現していることが分かる .ここで， 最大位置誤差は約 $120[\mathrm{~m}]$ 程度であり，飛行時間と飛行距 離，機体の速度を考慮すれば両モデルの飛行軌跡はよく一 致していると言える.第 19 図から第 22 図は，このケース

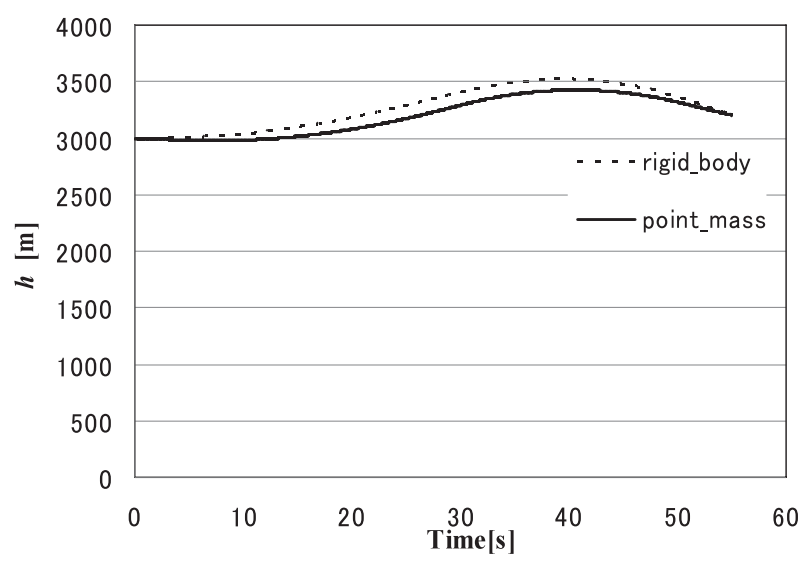

第 18 図高度の時間履歴

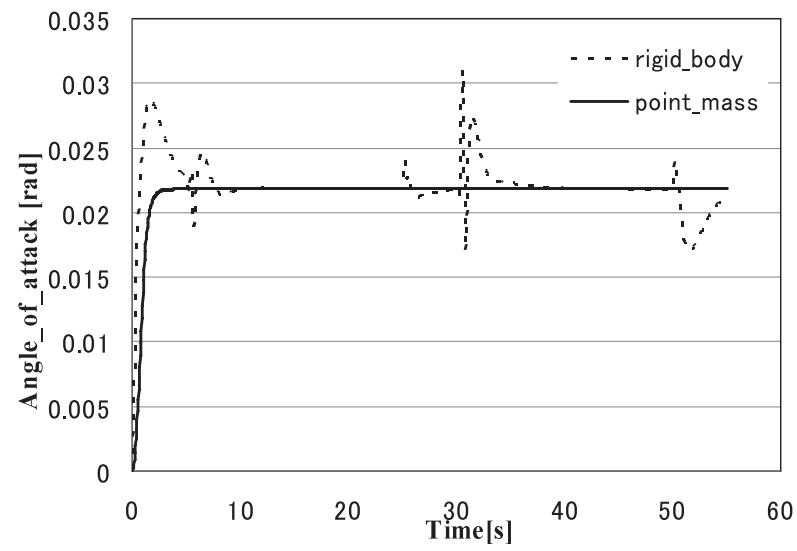

第 19 図 迎え角の時間履歴

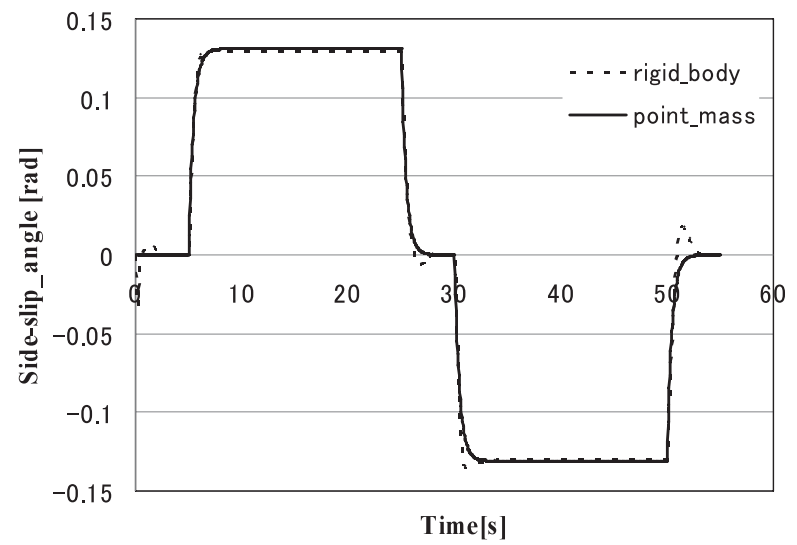

第 20 図 横滑り角の時間履歴

の各制御変数に関する時間履歴である . マヌーバ 1 と同じ く剛体モデルの出力には, 周波の高い制御入力が与えられ た部分においてオーバーシュートが生じており，この点で モデル間の相違が表れているのが分かるが , 全般的に両モ デル間において差は小さく，剛体モデルが質点モデルでよ く近似されていると言える

その他のマヌーバのシミュレーションにおいても，質点 モデルと剛体モデルの各制御変数は概ね一致することを確 認した . 特に , 高周波の制御入力を必要としない穏やかな 


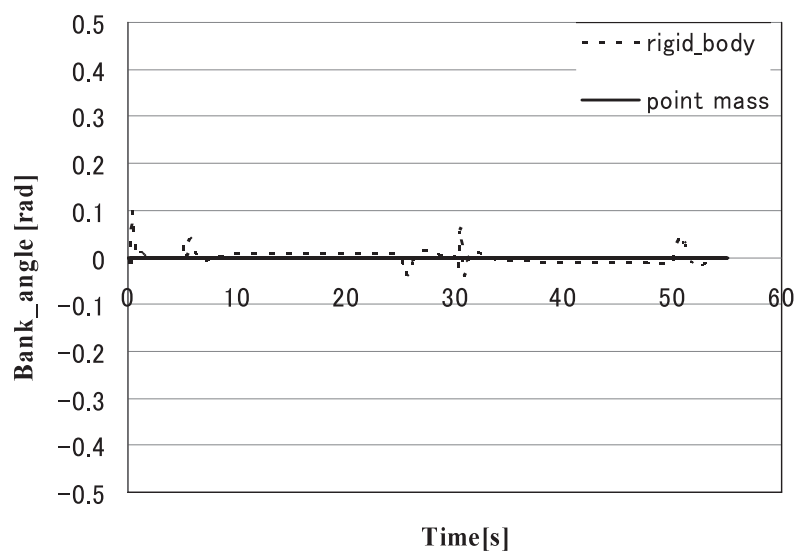

第 21 図 バンク角の時間履歴

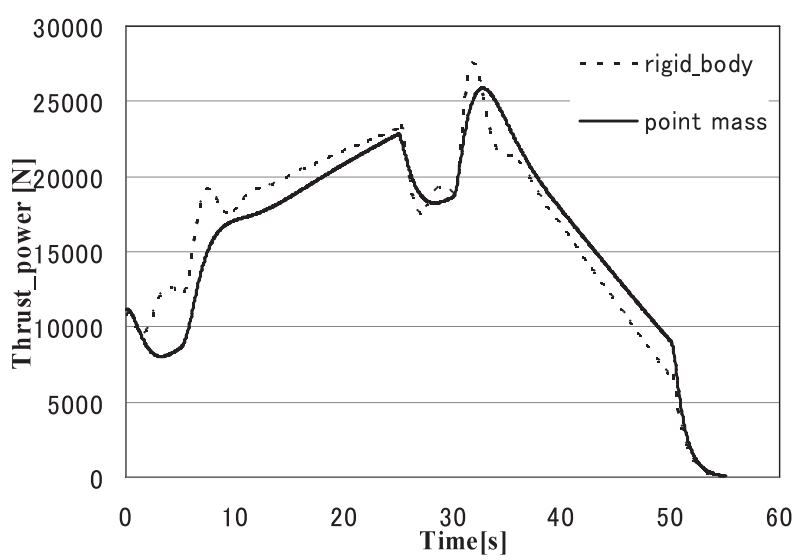

第 22 図 推力の時間履歴

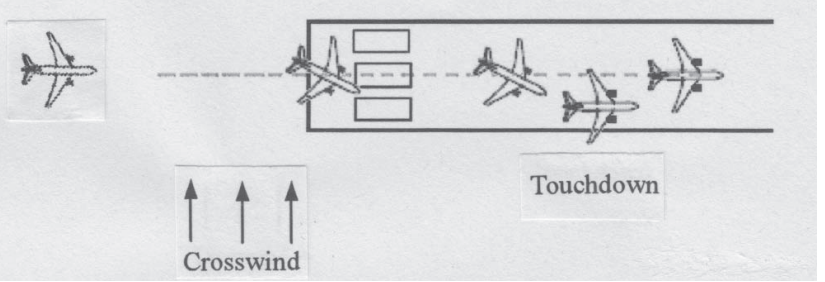

第 23 図 クラプ飛行による着陸

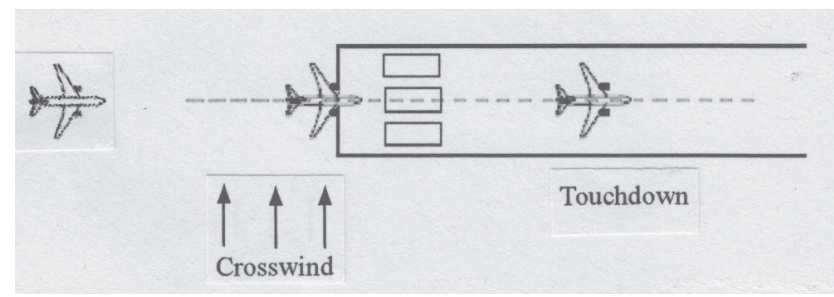

第 24 図 ウイングロー飛行による着陸

マヌーバの場合，両モデルの飛行軌跡は非常によく一致し た．しかしながら，僅かではあるが両モデル間において位 置誤差が生じている .これは本稿で用いた文献 3) の航空機 の空力係数か実際の航空機の風洞試験データによっており， $x-z$ 面に関して非対称となっているのに対して質点モデル では対称としていることに起因すると考えられる．なお飛

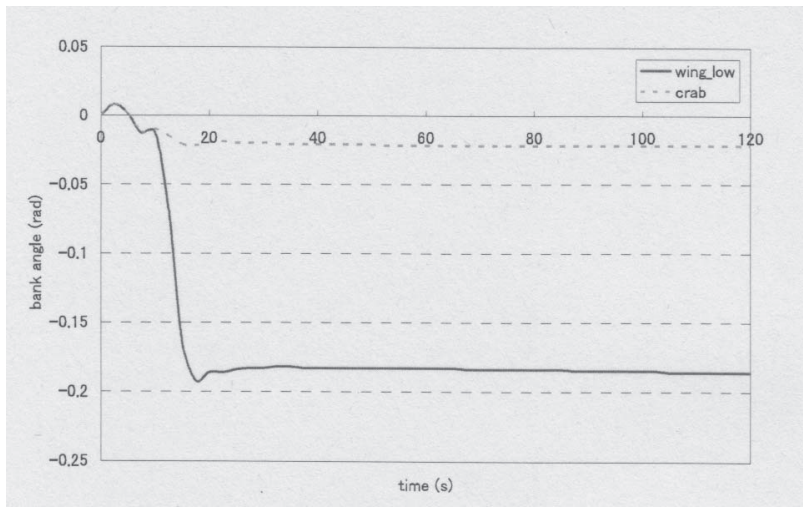

第 25 図 バンク角の時間履歴

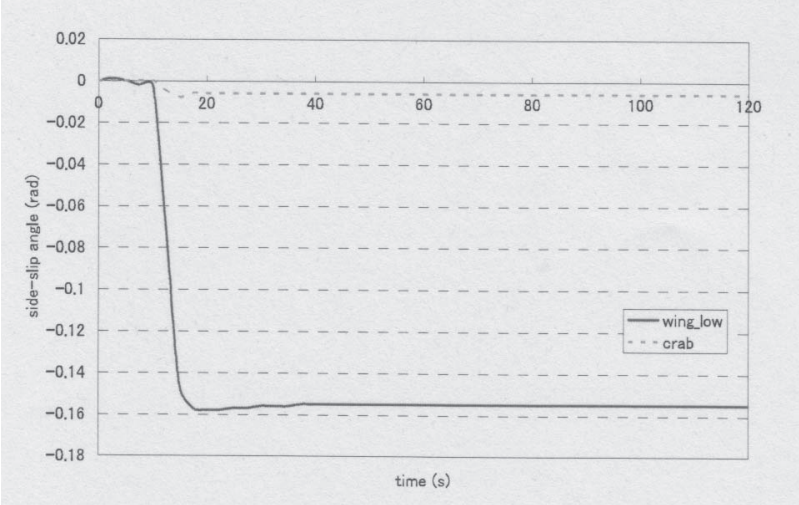

第 26 図 横滑り角の時間履歴

行軌跡をより正確に一致させたい場合の制御指令信号の修 正方法について文献 4) に示されている .

本論文において導いた質点モデルを用いた研究，特に最 適制御への応用は今後の課題であるが, 本質点モデルを用 いた，横風を受けた着陸シミュレーションの 1 例を以下に示 す.すなわち横風が有る場合に横滑り角を0に保ちつつ着 陸するためには第 23 図に示すクラフ飛行によらねばならな いが , 本質点モデルを用いれば第 24 図に示すウイングロー 飛行による着陸が可能である.図において航空機は $80 \mathrm{~m} / \mathrm{s}$ で接近し, シミュレーション開始後 10 秒後に $10 \mathrm{~m} / \mathrm{s}$ の横 風がステップ状に加わるとした . 第 25 図と第 26 図に乥れ ぞれバンク角と横滑り角の時間履歴を示す．

5. 結論

航空機の誘導制御系の研究において従来から迎え角，バ ンク角, 推力を制御変数とする質点モデルが使用されてき たが，剛体としての忠実な機体モデルに適用する場合，と りわけ風の有る場合の制御には適用できないので横滑り角 を制御変数として導入した 4 制御変数質点モデルを導出し た . 次にこの新しい質点モデルを用いて得られた航空機飛 行制御系の制御指令信号を剛体モデルに与えたときに同じ ように飛行するかの検討を行った . 兴のために質点モデル の制御指令信号に従って運動するように剛体モデルのオー トパイロットを設計して組み込んだ . 
2 つのマヌーバについて, 著者らが導いた 4 制御変数質 点モデルと剛体モデルを用いシミュレーションを行った結 果，両者の差は小さく十分な精度で岡体の航空機モデルに 適用できることが分かった．今後航空機の最適経路制御問 題などにこの 4 制御変数質点モデルを活用していく予定で ある

\section{参 考 文 献}

1) Kinoshita, T. and Imado, F.: The Application of an UAV Flight Simulator-The Development of a New Point Mass
Model for an Aircraft-, SICE-ICASE International Joint Conference 2006, FE-18-3, Korea, 2006.

2) Gilbert, W. P., Nguyan, L. T. and Van Gunst, R. W.: Simulator Study of Effectiveness of an Automatic Control System Designed to Improve the High-Angle-of-Attack Characteristics of a Fighter Airplane, NASA TN-8176, 1976.

3) 木下拓也, 今度史昭 : UAV フライト・シミュレータの開発と光 の応用，日本航空宇宙学会論文集，55 (2007), pp. 309-317.

4) 平家祐貴: 航空機の 4 制御変数質点モデルを用いた飛行シミュ レーションと非線形岡体モデルへの適用に関する一研究, 信州大 学平成 20 年度修士論文, 2009 . 